\title{
cmaJOPEN
}

\section{Topical nitroglycerin ointment as salvage therapy for peripheral tissue ischemia in newborns: a systematic review}

\author{
Katelyn Sushko BScN, Catherine Litalien MD, Lauren Ferruccio PharmD, Andrea Gilpin PhD MBA, \\ Maryann Mazer-Amirshahi MD PhD, Anthony K. Chan MBBS, John van den Anker MD PhD, \\ Thierry Lacaze-Masmonteil MD PhD, Samira Samiee-Zafarghandy MD
}

\section{Abstract}

Background: Topical nitroglycerin (TNG) ointment has been used for almost 3 decades to treat neonatal peripheral tissue ischemia, but this product is now no longer being produced by its Canadian manufacturer. Our aim was to investigate the efficacy and safety of TNG products in newborns in neonatal intensive care units.

Methods: In this systematic review we searched Embase, CINAHL, MEDLINE, PubMed and Web of Science from inception to April 2020 for studies on the use of TNG products (TNG ointment, TNG spray, glyceryl trinitrate [GTN] patch) for the treatment of neonatal tissue ischemia. We did not apply language or study design limitations. Animal studies and duplicate records were excluded. Two reviewers screened and extracted data. The Tool for Evaluating the Methodological Quality of Case Reports and Case Series was used to assess the risk of bias of individual studies.

Results: We included 23 articles (20 case reports, 2 case series and 1 retrospective audit) describing the use of TNG ointment, TNG spray or GTN patch in the treatment of 39 tissue ischemia events in 37 newborns. Twenty-three (62.2\%), $12(32.4 \%), 1(2.7 \%)$ and $1(2.7 \%)$ infants received TNG ointment, GTN patch, both TNG ointment and GTN patch, and TNG spray, respectively. Nineteen $(76.0 \%)$ and 7 (53.8\%) injuries treated with TNG ointment and GTN patch showed complete recovery, respectively. Two (16.7\%) infants treated with GTN patch experienced adverse events (i.e., methemoglobinemia) requiring treatment discontinuation.

Interpretation: TNG ointment presents a safe therapeutic modality for salvage therapy of neonatal tissue ischemia. Engagement of stakeholders is essential to address its recent commercial inaccessibility in Canada.

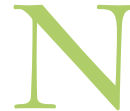
ewborns admitted to neonatal intensive care units (NICUs) require venous access, with or without arterial cannulation, to meet their therapeutic needs, including hemodynamic and nutritional balance. ${ }^{1}$ Although vascular catheterization is imperative, peripheral tissue ischemia is a well-described complication. ${ }^{2-6}$ Peripheral tissue ischemia is attributed primarily to extravasation of intravenous medication, peripheral vasospasm or a thromboembolic event secondary to percutaneous arterial access. ${ }^{7,8}$ The subsequent tissue injury is associated with substantial morbidity among newborns discharged from the NICU. Evidence on the incidence of tissue ischemia among infants who survive to leave the NICU is variable, but tissue ischemia has been reported in up to $10 \%$ of extremely low birth weight (ELBW) newborns, and up to $4 \%$ can experience severe tissue injuries. ${ }^{3-6}$

The current approach to neonatal peripheral tissue ischemia consists of conservative treatment (including removal of the device, elevation of the affected limb and application of warmth to the opposite limb [reflex vasodilation]), pharmacologic therapy (antithrombotic and fibrinolytic agents) and surgical management (surgical thrombectomy). Although pharmacosurgical approaches are promising options in older children, their use in sick newborns is limited because of the high risk of complications ${ }^{7,9}$

Topical nitroglycerin (TNG) products, which are approved in Canada for the prevention of angina pectoris in adults, have been used off label as salvage therapy for tissue ischemia in newborns since the 1980s, as per neonatal clinical practice guidelines. ${ }^{10-15}$ The efficacy of TNG appears to result from the vasodilatory effect of nitroglycerin on vascular smooth muscle. ${ }^{16}$

\section{Competing interests: None declared.}

This article has been peer reviewed.

Correspondence to: Katelyn Sushko, sushkokj@mcmaster.ca CMAJ Open 2021. DOI:10.9778/cmajo.20200129 
In July 2018, the sole Canadian manufacturer discontinued the production of TNG ointment, which has resulted in a shortage of this product. ${ }^{17}$ There is a need to examine the potential impact that this drug shortage may have on vulnerable newborns in Canada. Our aim in this study was to investigate the efficacy and safety of TNG products (TNG ointment, TNG spray and glyceryl trinitrate [GTN] patch) in newborns with peripheral tissue ischemia in NICUs and to explore whether any of the alternative TNG products have an efficacy and safety profile similar to that of TNG ointment.

\section{Methods}

\section{Study design}

We conducted a systematic review, using the foanna Briggs Institute Manual for Evidence Synthesis and the Preferred Reporting Items for Systematic Reviews and Meta-Analyses (PRISMA) statements for guidance. ${ }^{18,19}$ The protocol for this systematic review was not published. The PICO framework used for this review is described in Box 1.

\section{Data sources}

We systematically searched Ovid MEDLINE (1946-April 2020), PubMed (1809-April 2020), Embase (1974-April 2020), CINAHL (1937-April 2020) and Web of Science (1900-April 2020). The search strategy was developed in MEDLINE (OVID interface) and translated as appropriate for the other databases. The search strategies contained database-specific subject headings and text word terms for the concepts of nitroglycerin and neonatal intensive care. This strategy was developed and peer reviewed using the Peer Review of Electronic Search Strategies (PRESS) guideline in consultation with professional librarians (Appendix 1, available at www.cmajopen.ca/content/9/1/E252/suppl/ DC1). ${ }^{20} \mathrm{We}$ searched the bibliographies of relevant articles for additional references. Using Google Scholar, we searched for studies that are not commercially published, such as conference abstracts, dissertations and policy documents.

\section{Box 1: PICO framework}

Population: The population of interest was preterm and term newborns in the neonatal intensive care unit who have peripheral tissue ischemia.

Intervention: The intervention was the application of topical nitroglycerin products, defined as nitroglycerin ointment, nitroglycerin spray or glyceryl trinitrate patch, to the area of peripheral tissue ischemia.

Comparison: The comparator was standard of care or any other therapeutic intervention without the application of topical nitroglycerin products (ointment, nitroglycerin spray or glyceryl trinitrate patch).

Outcome: The outcome of interest was the effect of application of topical nitroglycerin products (nitroglycerin ointment, nitroglycerin spray, or glyceryl trinitrate patch) on the area of peripheral tissue ischemia, such as no effect, partial resolution (e.g., loss of finger or toe or reported neurovascular changes in the affected limb) or complete resolution.

\section{Study selection}

All randomized controlled trials (RCTs), cohort studies, case reports and study abstracts describing the use of TNG ointment, TNG spray or GTN patch in the NICU-based treatment of tissue ischemia in newborns of any gestational age and postnatal age were eligible for inclusion, irrespective of the dose, administration frequency and duration of treatment. We did not apply any language or study design limitations. Animal studies and duplicate studies were excluded. Standard practice or any other therapeutic intervention was the comparator in studies with a control group. If there was no comparator group, the reported efficacy and safety of TNG ointment or GTN patch were extracted.

\section{Data extraction}

Following the database searches, 2 reviewers (K.S., S.S-Z.) screened all articles independently and in duplicate at the title and abstract level. They then independently reviewed all full-text articles meeting the inclusion criteria and extracted data. Any disagreements were resolved through discussion with a third reviewer (C.L.). We used a standardized data collection form to extract the relevant data from the included studies (Table 1).

\section{Data quality assessment}

We used the Tool for Evaluating the Methodological Quality of Case Reports and Case Series ${ }^{21}$ to assess the risk of bias of individual studies. All studies were independently assessed by 2 reviewers (K.S. and S.S-Z). Disagreements were discussed and resolved among 3 reviewers (K.S., S.S-Z., C.L).

\section{Data analysis}

We conducted a narrative synthesis of the study results, the structure of which was based on the modality of nitroglycerin application. For each modality, we described the number of newborns and injuries treated, the time from injury to treatment initiation, the time from application to first effect, the treatment duration, the number of injuries showing complete recovery, adverse events and adjunctive therapy. As none of the included articles reported effect estimate statistics, a metaanalysis was not conducted.

\section{Ethics approval}

We did not seek ethics approval as we used publicly available evidence for our study.

\section{Resullts}

A total of 892 articles were identified (Figure 1). Following removal of duplicates, 589 articles were screened at the title and abstract level and 23 at the full-text level. Twenty-three studies were included in the final review. ${ }^{22-44}$ Twenty articles were case reports, ${ }^{22-39,41,43,44} 2$ were case series ${ }^{35,40}$ and 1 was an abstract of a retrospective audit ${ }^{42}$ (Table 1, Table 2).

\section{Characteristics of studies}

We identified 23 studies describing 37 newborns with 39 peripheral tissue ischemic events treated with TNG ointment 


\begin{tabular}{|c|c|c|c|c|c|}
\hline Study & Design & $\begin{array}{l}\text { Gestational } \\
\text { age, wk }\end{array}$ & $\begin{array}{l}\text { Postnatal } \\
\text { age, d }\end{array}$ & Cause of ischemia & Ischemic site \\
\hline \multicolumn{6}{|c|}{ Intervention: topical nitroglycerin ointment } \\
\hline Denkler and Cohen ${ }^{43}$ & Case report & 34 & 1 & Dopamine extravasation & $\begin{array}{l}\text { Left hand to low forearm, } \\
\text { left foot to knee }\end{array}$ \\
\hline Wong et al. ${ }^{40}$ & Case series & $\begin{array}{l}25 \\
24 \\
31 \\
26\end{array}$ & $\begin{array}{c}10 \\
40 \\
4 \\
15\end{array}$ & $\begin{array}{c}\text { PAL } \\
\text { PAL } \\
\text { Dopamine extravasation } \\
\text { Dopamine extravasation }\end{array}$ & $\begin{array}{l}\text { Right hand } \\
\text { Right hand } \\
\text { Forearm, chest, axilla } \\
\text { Forearm, arm }\end{array}$ \\
\hline Baserga et al. ${ }^{25}$ & Case report & $\begin{array}{l}30 \\
25 \\
23\end{array}$ & $\begin{array}{c}1 \\
1 \\
10\end{array}$ & $\begin{array}{l}\text { UAC } \\
\text { UAC } \\
\text { PAL }\end{array}$ & $\begin{array}{c}\text { Left leg, penis, scrotum } \\
\text { Right leg } \\
\text { Left hand }\end{array}$ \\
\hline Vasquez et al. ${ }^{30}$ & Case report & 26 & 1 & PAL & Left hand \\
\hline Mousavi et al. ${ }^{38}$ & Case report & 32 & 2 & UVC & Right leg and foot \\
\hline Akingbola et al. ${ }^{34}$ & Case report & 31 & 60 & PAL & Left leg, foot and toes \\
\hline Mosalli et al. ${ }^{35}$ & $\begin{array}{l}\text { Case report } \\
\text { Case report }\end{array}$ & $\begin{array}{l}25 \\
26\end{array}$ & $\begin{array}{l}14 \\
1.5\end{array}$ & $\begin{array}{l}\text { PAL } \\
\text { PIV }\end{array}$ & $\begin{array}{l}\text { Right finger } \\
\text { Left foot }\end{array}$ \\
\hline Samiee-Zafarghandy et al. ${ }^{22}$ & Case report & 26 & 1.5 & PIV & Left foot \\
\hline Dilli et al. ${ }^{33}$ & Case report & 28 & 5 & UAC & Lower limbs \\
\hline Parra et al. ${ }^{29}$ & Case report & 32 & 49 & $\begin{array}{c}\text { Thrombin injection into } \\
\text { PSA sac }\end{array}$ & Right arm \\
\hline Vivar del Hoyo et al. ${ }^{24}$ & Case series & $\begin{array}{c}24 \\
35 \\
>37 \\
>37\end{array}$ & NS & $\begin{array}{l}\text { UAC/UVC } \\
\text { PICC } \\
\text { PICC } \\
\text { PICC }\end{array}$ & $\begin{array}{l}\text { Toes } \\
\text { Fingers } \\
\text { Fingers } \\
\text { Fingers }\end{array}$ \\
\hline Han et al. ${ }^{37}$ & Case report & 24 & 5 & PAL & Upper limb \\
\hline Isik et al. ${ }^{36}$ & Case report & 34 & NS & PIV phenytoin infusion & Upper limb \\
\hline Kuttysankaran et al..$^{32}$ & Case report & Term & 1 & $\begin{array}{l}\text { Spontaneous femoral } \\
\text { artery thrombosis }\end{array}$ & Lower limb \\
\hline Weeraskera et al. ${ }^{27}$ & Case report & 26 & 5 & PIV & Fingers \\
\hline \multicolumn{6}{|c|}{ Intervention: glyceryl trinitrate patch } \\
\hline O'Reilly et al. ${ }^{28}$ & Case report & NS & NS & TPN extravasation & Dorsum of foot \\
\hline Varughese et al. ${ }^{41}$ & Case report & 33 & 10 & UAC & Right hip \\
\hline Maffei et al. ${ }^{23}$ & Case report & $\begin{array}{l}29 \\
32\end{array}$ & $\begin{array}{l}1 \\
8\end{array}$ & $\begin{array}{c}\text { Central venous catheter } \\
\text { PAL }\end{array}$ & $\begin{array}{l}\text { Left arm } \\
\text { Right arm }\end{array}$ \\
\hline Teo and Shah ${ }^{31}$ & Case report & 32 & NS & PICC & Upper limb \\
\hline Yong et al..$^{42}$ & $\begin{array}{c}\text { Retrospective } \\
\text { audit }\end{array}$ & $<31$ & $<14->28$ & PAL & NS \\
\hline Mintoft et al. ${ }^{26}$ & Case report & $\begin{array}{l}24 \\
24\end{array}$ & $\stackrel{1}{3,7}$ & $\begin{array}{c}\text { Spontaneous, PAL } \\
\text { PAL }\end{array}$ & $\begin{array}{l}\text { Lower limbs, thumb, } \\
\text { forefinger; } \\
\text { Toes }\end{array}$ \\
\hline \multicolumn{6}{|c|}{ Intervention: topical nitroglycerin ointment and glyceryl trinitrate patch } \\
\hline Ancora et al. ${ }^{39}$ & Case report & 28 & 1 & UVC & $\begin{array}{c}\text { Right fingers, right and left } \\
\text { toes }\end{array}$ \\
\hline \multicolumn{6}{|c|}{ Intervention: topical nitroglycerin spray } \\
\hline Kamar et al. ${ }^{44}$ & Case report & 25 & $>1 \mathrm{~d}$ & PAL & Toes, fingers \\
\hline
\end{tabular}

(23 newborns, 62.2\%), GTN patch (12 newborns, 32.4\%), TNG ointment plus GTN patch (1 newborn, $2.7 \%$ ) and TNG spray (1 newborn, $2.7 \%$ ) (Table 1 , Table 2$)$. The majority of the newborns were born extremely or very preterm (25 newborns, $67.6 \%$ ) and were within the first 2 weeks of life at the time of injury (26 newborns, $70.3 \%$ ). The mean gestational age 


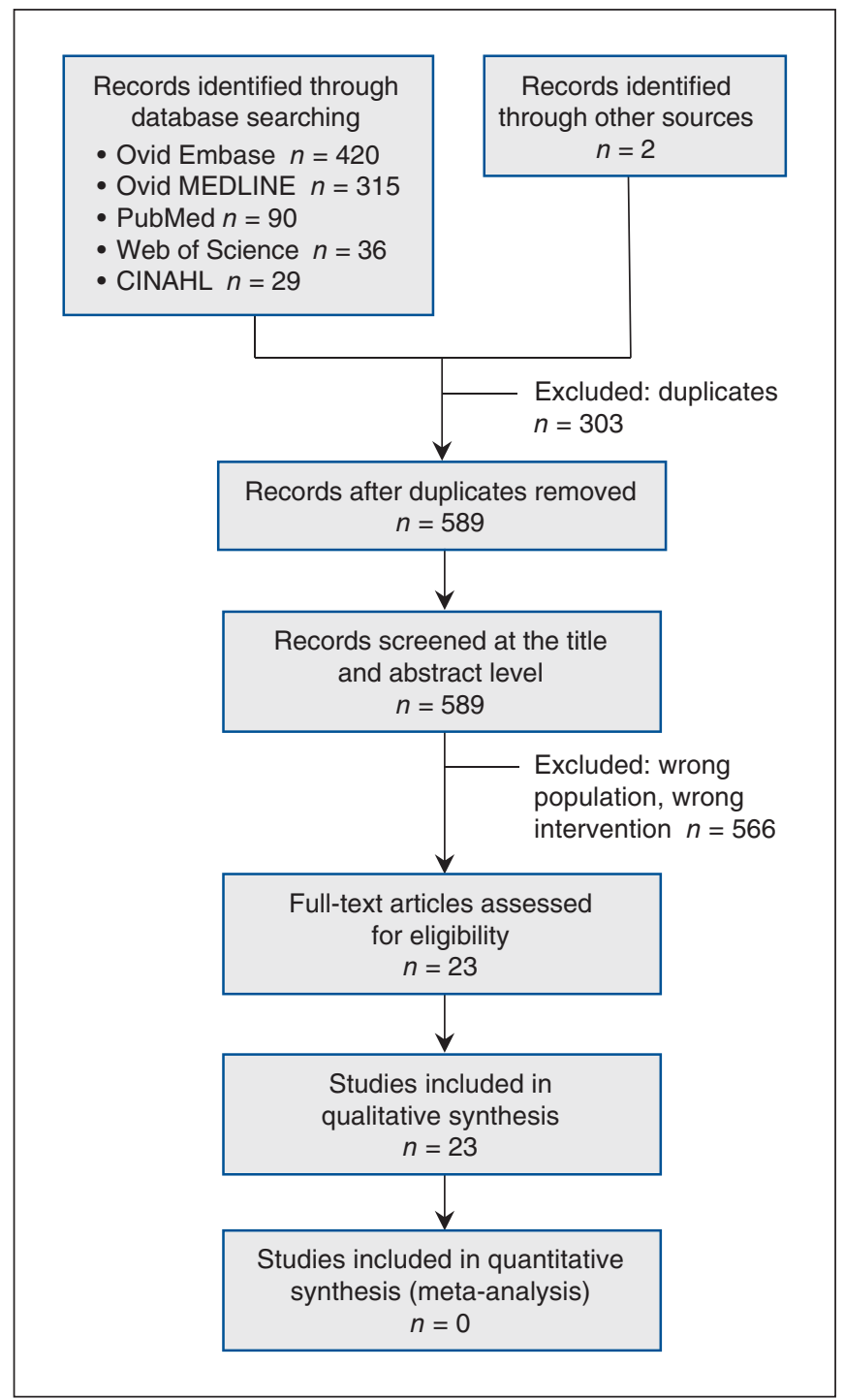

Figure 1: Flow diagram showing the study screening and selection process.

was 29.1 weeks (range 23 wk to term). Placement of an umbilical artery catheter or peripheral arterial line (PAL) was the most common cause of identified tissue ischemia (22 events, $56.1 \%$ ), followed by intravenous drug administration (5 events, $12.8 \%$ ). Mean treatment duration was 10.4 days (range 1 dose to $36 \mathrm{~d}$ ).

\section{Treatment details}

\section{TNG ointment}

Twenty-three neonates received TNG ointment for 25 peripheral tissue ischemic events (Table 1, Table 2). ${ }^{22,24,25,27,29,30,32-38,40,43}$ Initiation of treatment was delayed by up to 6 days. Time from application to first effect varied from 15 minutes to 23 days. Treatment duration ranged from 1 dose to 36 days; 19 (76.0\%) injuries showed complete recovery. $24,25,27,29,30,32,33,35,37,40,43$

Four adverse events were reported in newborns treated with TNG ointment: 3 were mild blood pressure and heart rate changes that resolved without discontinuation of treatment, and 1 was an occurrence of swelling bulla that resolved with the application of Xeroform gauze and limb elevation. ${ }^{25,34,40}$ Six of the 23 newborns treated with TNG ointment received adjunctive therapy, which included tissue plasminogen activator, heparin, intravenous nitroglycerin, $100 \%$ humidity and milrinone. ${ }^{27,29,33,34,36,37}$ One infant who experienced embolization of a broken arterial catheter tip was first treated by removing the catheter fragment using angiography. ${ }^{33}$

Four infants with peripheral tissue injury treated with TNG ointment did not experience a complete recovery. They ranged in gestational age from 26 to 34 weeks and experienced a peripheral tissue injury following placement of 1 umbilical venous catheter, $1 \mathrm{PAL}$, and 2 peripheral intravenous lines. ${ }^{22,34,36,38}$ Treatment initiation was delayed up to 6 days and treatment duration was up to 21 days. Outcomes ranged from reduced limb movement and reflexes to death.

\section{GTN patch}

Twelve newborns received GTN patches for 13 peripheral tissue ischemic events (Table 1, Table 2). ${ }^{23,26,28,31,41,42}$ Time of application of GTN patch after injury ranged from immediately to 12 hours. Maximum duration of treatment was 7 days; treatment was discontinued in 2 patients because of serious adverse events. ${ }^{26}$ Seven of the 13 injuries (53.8\%) showed complete recovery. ${ }^{23,26,28,31,41,42}$ Six of the 12 newborns treated with the GTN patch received adjunctive therapies that included enoxaparin, heparin and tissue plasminogen activator. ${ }^{31,42}$

Two newborns experienced methemoglobinemia subsequent to the use of the GTN patch. ${ }^{26}$ In both cases, a 9- $\mathrm{cm}^{2}$ patch $(18.7 \mathrm{mg})$ was applied to the sites of injury. The first newborn received 3 GTN patches for 2 tissue ischemic events (1 spontaneous event after birth and 1 event after PAL insertion) over 48 hours. Two patches were applied on the first day of life and the third patch was applied on the second day of life. Within 6 hours following application of the third patch, the infant's oxygen requirements increased from $21 \%$ to $40 \%$ and methemoglobin level rose from $1.1 \%$ to $8.4 \%$. In the second case, GTN patches were applied for tissue injury following PAL insertion. One patch was applied on the third day of life and changed daily until the seventh day of life, when 2 patches were applied and changed twice daily, with a total of 10 patches used in 5 days. Within 24 hours of the application of 2 patches on the seventh day of life, the infant's oxygen requirement increased from $23 \%$ to $70 \%$ and the methemoglobin level increased to $23.3 \%$. Symptoms of methemoglobinemia ceased within 24 hours of patch removal. One other infant experienced a decrease in blood pressure, which resolved with inotropic adjustment. ${ }^{41}$

\section{GTN patch and TNG ointment}

One infant was treated with GTN patch and TNG ointment (Table 1, Table 2). ${ }^{39}$ The patch was applied to the injury for 5 days as an alternative to TNG ointment as the latter was initially unavailable. Once the ointment became available, the patch was removed and ointment was applied for 11 days, along with an antibiotic cream. Following ointment application, rapid improvement was observed, with increased vascularization and hyperemia of the ischemic tissue. No adverse 
Table 2 (part 1 of 2): Interventions and outcomes in studies of the use of topical nitroglycerin ointment, topical nitroglycerin spray and glyceryl trinitrate patch in neonatal peripheral tissue ischemia

\begin{tabular}{|c|c|c|c|c|c|c|c|c|}
\hline \multirow[b]{2}{*}{ Study } & \multicolumn{5}{|c|}{ Intervention } & \multicolumn{3}{|c|}{ Outcome } \\
\hline & Time, $\mathrm{h}^{*}$ & Strength & Dose & $\begin{array}{l}\text { Time to } \\
\text { first } \\
\text { effect† }\end{array}$ & $\begin{array}{l}\text { Treatment } \\
\text { duration }\end{array}$ & $\begin{array}{l}\text { Adjunctive } \\
\text { therapy }\end{array}$ & Outcome & Adverse events \\
\hline \multicolumn{9}{|c|}{ Intervention: topical nitroglycerin ointment } \\
\hline $\begin{array}{l}\text { Denkler and } \\
\text { Cohen }^{43}\end{array}$ & 6 & $2 \%$ & $\begin{array}{c}14 \\
\mathrm{~mm} / \mathrm{kg} \ddagger\end{array}$ & Minutes & 1 dose & None reported & $\mathrm{CR}$ & No \\
\hline Wong et al. ${ }^{40}$ & $\begin{array}{c}2 \\
<24 \\
1 \\
0.5\end{array}$ & $\begin{array}{l}2 \% \\
2 \% \\
2 \% \\
2 \%\end{array}$ & $\begin{array}{l}4 \mathrm{~mm} / \mathrm{kg} \\
4 \mathrm{~mm} / \mathrm{kg} \\
4 \mathrm{~mm} / \mathrm{kg} \\
4 \mathrm{~mm} / \mathrm{kg}\end{array}$ & $\begin{array}{l}15 \mathrm{~min} \\
8 \mathrm{~h} \\
15 \mathrm{~min} \\
8 \mathrm{~h}\end{array}$ & $\begin{array}{c}1 \text { dose } \\
12 \mathrm{~h} \\
1 \text { dose } \\
24 \mathrm{~h}\end{array}$ & $\begin{array}{l}\text { None reported } \\
\text { None reported } \\
\text { None reported } \\
\text { None reported }\end{array}$ & $\begin{array}{l}\text { CR } \\
\text { CR } \\
\text { CR } \\
\text { CR }\end{array}$ & $\begin{array}{c}\text { No } \\
\downarrow B P \\
\text { No } \\
\downarrow B P, \uparrow H R\end{array}$ \\
\hline $\begin{array}{l}\text { Baserga et } \\
\text { al. } .^{25}\end{array}$ & $\begin{array}{c}1 \\
1.5 \\
1\end{array}$ & $\begin{array}{l}2 \% \\
2 \% \\
2 \%\end{array}$ & $\begin{array}{l}4 \mathrm{~mm} / \mathrm{kg} \\
4 \mathrm{~mm} / \mathrm{kg} \\
4 \mathrm{~mm} / \mathrm{kg}\end{array}$ & $\begin{array}{l}30 \mathrm{~min} \\
45 \mathrm{~min} \\
30 \mathrm{~min}\end{array}$ & $\begin{array}{l}1 \text { dose } \\
1 \text { dose } \\
1 \text { dose }\end{array}$ & $\begin{array}{l}\text { None reported } \\
\text { None reported } \\
\text { None reported }\end{array}$ & $\begin{array}{l}\mathrm{CR} \\
\mathrm{CR} \\
\mathrm{CR}\end{array}$ & $\begin{array}{l}\text { No } \\
\text { No } \\
\downarrow B P\end{array}$ \\
\hline $\begin{array}{l}\text { Vasquez et } \\
\text { al. }{ }^{30}\end{array}$ & 7 & $2 \%$ & $\begin{array}{c}<4 \\
\mathrm{~mm} / \mathrm{kg}\end{array}$ & $8 \mathrm{~h}$ & $27 d$ & None reported & CR & No \\
\hline $\begin{array}{l}\text { Mousavi et } \\
\text { al. }{ }^{38}\end{array}$ & NS & $2 \%$ & $4 \mathrm{~mm} / \mathrm{kg}$ & NR & NS & None reported & Death & No \\
\hline $\begin{array}{l}\text { Akingbola et } \\
\text { al. }^{34}\end{array}$ & $<24$ & $2 \%$ & $4 \mathrm{~mm} / \mathrm{kg}$ & $24 \mathrm{~h}$ & $21 d$ & tPA, heparin & $\begin{array}{l}\text { Loss of tip } \\
\text { of left great } \\
\text { toe }\end{array}$ & Swelling bulla \\
\hline Mosalli et al. ${ }^{35}$ & NS & $2 \%$ & $\begin{array}{c}<4 \\
\mathrm{~mm} / \mathrm{kg}\end{array}$ & $8 \mathrm{~h}$ & $21 d$ & None reported & CR & No \\
\hline $\begin{array}{l}\text { Samiee- } \\
\text { Zafarghandy } \\
\text { et al. }{ }^{22}\end{array}$ & 144 & $2 \%$ & $4 \mathrm{~mm} / \mathrm{kg}$ & $24 \mathrm{~h}$ & $14 d$ & None reported & $\begin{array}{l}\text { Lost } \\
\text { second and } \\
\text { third toes }\end{array}$ & No \\
\hline Dilli et al. ${ }^{33}$ & NS & $2 \%$ & $4 \mathrm{~mm} / \mathrm{kg}$ & $3 d$ & $15 d$ & $\begin{array}{l}\text { tPA, heparin, } \\
\text { intravenous } \\
\text { nitroglycerin }\end{array}$ & CR & No \\
\hline Parra et al. ${ }^{29}$ & NS & NS & NS & NS & NS & Heparin & $\mathrm{CR}$ & No \\
\hline $\begin{array}{l}\text { Vivar del Hoyo } \\
\text { et al. }{ }^{24}\end{array}$ & $\begin{array}{l}\text { First hours } \\
\text { after } \\
\text { ischemia }\end{array}$ & $2 \%$ & $4 \mathrm{~mm} / \mathrm{kg}$ & NS & $5-18 d$ & None reported & CR & No \\
\hline Han et al. ${ }^{37}$ & 48 & $2 \%$ & $4 \mathrm{~mm} / \mathrm{kg}$ & $23 \mathrm{~d} \S$ & $36 d$ & $100 \%$ humidity & $\mathrm{CR}$ & No \\
\hline Isik et al. ${ }^{36}$ & NS & NS & NS & Weeks & NS & Heparin & $\begin{array}{l}\text { Reduced } \\
\text { movement } \\
\text { and } \\
\text { reflexes, } \\
\text { muscle } \\
\text { atrophy }\end{array}$ & No \\
\hline $\begin{array}{l}\text { Kuttysankaran } \\
\text { et al. }{ }^{32}\end{array}$ & NS & NS & NS & $2 d$ & $4 d$ & None reported & $\mathrm{CR}$ & No \\
\hline $\begin{array}{l}\text { Weeraskera et } \\
\text { al. }{ }^{27}\end{array}$ & NS & NS & $4 \mathrm{~mm} / \mathrm{kg}$ & $18 \mathrm{~h}$ & $14 d$ & $\begin{array}{l}\text { Heparin, } \\
\text { milrinone }\end{array}$ & $\mathrm{CR}$ & No \\
\hline \multicolumn{9}{|c|}{ Intervention: glyceryl trinitrate patch } \\
\hline $\begin{array}{l}\text { O'Reilly et } \\
\text { al. }{ }^{28}\end{array}$ & 2.5 & $0.2 \mathrm{mg}$ & NS & NS & $1 \mathrm{~h}$ & None reported & $\mathrm{CR}$ & No \\
\hline $\begin{array}{l}\text { Varughese } \\
\text { and Koh }{ }^{41}\end{array}$ & 4 & $0.4 \mathrm{mg}$ & NS & $7 \mathrm{~h}$ & $30 \mathrm{~h}$ & None reported & $\mathrm{CR}$ & $\downarrow \mathrm{BP}$ \\
\hline
\end{tabular}




\begin{tabular}{|c|c|c|c|c|c|c|c|c|}
\hline \multirow[b]{2}{*}{ Study } & \multicolumn{5}{|c|}{ Intervention } & \multicolumn{3}{|c|}{ Outcome } \\
\hline & Time, $\mathrm{h}^{*}$ & Strength & Dose & $\begin{array}{l}\text { Time to } \\
\text { first } \\
\text { effect† }\end{array}$ & $\begin{array}{l}\text { Treatment } \\
\text { duration }\end{array}$ & $\begin{array}{l}\text { Adjunctive } \\
\text { therapy }\end{array}$ & Outcome & Adverse events \\
\hline \multicolumn{9}{|c|}{ Intervention: glyceryl trinitrate patch } \\
\hline Maffei et al. ${ }^{23}$ & $\begin{array}{c}0.5 \\
1\end{array}$ & \multicolumn{2}{|c|}{$\begin{array}{l}\text { 1- } \mathrm{cm}^{2} \text { patch containing } \\
\text { glyceryl trinitrate } \\
5 \mathrm{mg} \text { per } 7 \mathrm{~cm}^{2}\end{array}$} & $\begin{array}{l}1 \mathrm{~h} \\
3 \mathrm{~h}\end{array}$ & $\begin{array}{l}7 d \\
4 d\end{array}$ & $\begin{array}{l}\text { None reported } \\
\text { None reported }\end{array}$ & $\begin{array}{l}\text { CR } \\
\text { CR }\end{array}$ & $\begin{array}{l}\text { No } \\
\text { No }\end{array}$ \\
\hline $\begin{array}{l}\text { Teo and } \\
\text { Shah }{ }^{31}\end{array}$ & $\begin{array}{l}12 \mathrm{~h} \text { after } \\
\text { heparin } \\
\text { initiation }\end{array}$ & NS & NS & $5 d$ & $7 d$ & $\begin{array}{l}\text { Heparin, } \\
\text { enoxaparin }\end{array}$ & $\mathrm{CR}$ & No \\
\hline Yong et al. ${ }^{42}$ & NS & NS & NS & NS & NS & tPA, heparin & $\begin{array}{l}4 \mathrm{NR} \\
1 \mathrm{CR}\end{array}$ & No \\
\hline Mintoft et al. ${ }^{26}$ & Immediately & $\begin{array}{r}9-\mathrm{cm} \\
\text { contain }\end{array}$ & $\begin{array}{l}\text { hes } \\
3.7 \mathrm{mg}\end{array}$ & NS & $\begin{array}{l}2 \mathrm{~d} \eta \\
5 \mathrm{~d} \|\end{array}$ & & $\begin{array}{l}\text { CR } \\
\text { Loss of tips } \\
\text { of toes }\end{array}$ & $\begin{array}{l}\text { Methemoglobinemia } \\
\text { Methemoglobinemia }\end{array}$ \\
\hline \multicolumn{9}{|c|}{ Intervention: topical nitroglycerin ointment and glyceryl trinitrate patch } \\
\hline Ancora et al. ${ }^{39}$ & $\begin{array}{c}\text { At } 8 \mathrm{~h} \text { of life } \\
120\end{array}$ & NS & NS & NS & $\begin{array}{l}5 d \\
11 d\end{array}$ & $\begin{array}{l}\text { Antibiotic } \\
\text { cream }\end{array}$ & $\begin{array}{l}\text { Partial loss } \\
\text { of distal } \\
\text { finger and } \\
\text { toe }\end{array}$ & No \\
\hline \multicolumn{9}{|c|}{ Intervention: topical nitroglycerin spray } \\
\hline Kamar et al. ${ }^{44}$ & NS & NS & NS & NS & $7 d$ & None reported & $\begin{array}{l}\text { Partial loss } \\
\text { of distal } \\
\text { finger and } \\
\text { toe }\end{array}$ & No \\
\hline $\begin{array}{l}\text { Note: BP = blood } \\
\text { * Start time of inter } \\
\text { †Time between th } \\
\text { † We calculated th } \\
\text { §Improvement ob } \\
\text { qTreatment discor }\end{array}$ & $\begin{array}{l}\text { ssure, CR = comp } \\
\text { ntion after the tiss } \\
\text { tart of treatment } \\
\text { dose by convertin } \\
\text { ved } 23 \mathrm{~d} \text { after adr } \\
\text { ued because of } m\end{array}$ & $\begin{array}{l}\text { te resolution } \\
\text { injury. } \\
\text { h the nitrogly } \\
1 \text { inch of oint } \\
\text { sion to the n } \\
\text { hemoglobine }\end{array}$ & $\begin{array}{l}\text { heart rate, } \\
\text { roduct and } \\
\text { specified b) } \\
\text { al intensive }\end{array}$ & $\begin{array}{l}\text { = no resp } \\
\text { e first signs } \\
\text { enkler and } \\
\text { re unit. }\end{array}$ & $\begin{array}{l}\text {, NS }=\text { not st } \\
\text { mproved perf } \\
\text { en }{ }^{43} \text { ) to millim }\end{array}$ & $\begin{array}{l}\mathrm{d}, \mathrm{tPA}=\text { tissue plas } \\
\text { on recorded by the } \\
\text { res and dividing by }\end{array}$ & $\begin{array}{l}\text { nogen activator. } \\
\text { ponsible care pro } \\
\text { infant's weight } 0\end{array}$ & ider. \\
\hline
\end{tabular}

events occurred throughout treatment with either the patch or the ointment. Following treatment, partial loss of the distal phalange of 1 finger and 1 toe occurred.

\section{TNG spray}

One neonate with 2 peripheral tissue injuries (on 1 toe and 1 finger) was treated with TNG spray (Table 1 , Table 2). ${ }^{44}$ Nitroglycerin was sprayed on a compress that was applied to the sites of injury every 8 hours for 7 days. Upon application of the compress, the area of tissue injury became warm, and capillary refill normalized. However, necrosis was still visible on the toe and finger after 7 days, at which time treatment was discontinued. Follow-up at 2 months of age found that the tip of the affected finger and toe had fallen off.

\section{Risk of bias assessment}

All included studies were evaluated across 4 domains to determine the risk of selection bias, ascertainment bias, causality bias and reporting bias. Selection and causality were identified as 2 domains through which bias might have been introduced in the majority of studies (Table 3).

\section{Interpretation}

In this systematic review, treatment of tissue ischemic injuries in newborns with TNG ointment appears to be efficacious, with complete recovery of $76.0 \%$ of injuries treated with ointment. In the 4 cases in which recovery was incomplete, extenuating circumstances might have mitigated the ointment's efficacy. In 1 case, the infant had reduced limb movement and reflexes with muscle atrophy at discharge as a result of purple glove syndrome, ${ }^{36}$ a condition that is known to progress to compartment syndrome requiring fasciotomy, skin grafting or amputation in adults. Several mechanisms have been described for the pathophysiology of this syndrome, from tissue infiltration to venous obstruction secondary to extravasation of a highly alkaline substance (phenytoin). ${ }^{45}$ Given this complex pathology, application of TNG ointment may not be sufficient in such cases. In the remaining cases, short duration of treatment or prolonged lag time to the start of treatment might have contributed to incomplete recovery. ${ }^{22,34,38}$

On the basis of the limited available evidence, TNG ointment seems to be well tolerated in newborns, with no serious 


\begin{tabular}{|c|c|c|c|c|c|c|c|}
\hline Study & $\begin{array}{l}\text { Is (are) the } \\
\text { patient(s) } \\
\text { representative of } \\
\text { the investigating } \\
\text { centre? }\end{array}$ & $\begin{array}{l}\text { Was the } \\
\text { exposure/ } \\
\text { outcome } \\
\text { adequately } \\
\text { ascertained? }\end{array}$ & $\begin{array}{l}\text { Was an } \\
\text { alternative } \\
\text { cause } \\
\text { ruled out? }\end{array}$ & $\begin{array}{c}\text { Was there a } \\
\text { challenge- } \\
\text { rechallenge } \\
\text { phenomenon? }\end{array}$ & $\begin{array}{l}\text { Was there a } \\
\text { dose- } \\
\text { response } \\
\text { effect? }\end{array}$ & $\begin{array}{l}\text { Was } \\
\text { follow- } \\
\text { up long } \\
\text { enough? }\end{array}$ & $\begin{array}{c}\text { Quality of } \\
\text { reporting, } \\
\text { description }\end{array}$ \\
\hline O'Reilly et al. ${ }^{28}$ & $\begin{array}{l}\text { Patient selection } \\
\text { method NS }\end{array}$ & Yes/yes & Yes & No & No & Yes & Yes \\
\hline $\begin{array}{l}\text { Denkler and } \\
\text { Cohen }{ }^{43}\end{array}$ & $\begin{array}{l}\text { Patient selection } \\
\text { method NS }\end{array}$ & Yes/yes & Yes & No & No & Yes & Yes \\
\hline Wong et al. ${ }^{40}$ & $\begin{array}{l}\text { Patient selection } \\
\text { method NS }\end{array}$ & Yes/yes & Yes & No & No & Yes & Yes \\
\hline Baserga et al. ${ }^{25}$ & $\begin{array}{l}\text { Patient selection } \\
\text { method NS }\end{array}$ & Yes/yes & Yes & No & No & Yes & Yes \\
\hline Vasquez et al. ${ }^{30}$ & $\begin{array}{l}\text { Patient selection } \\
\text { method NS }\end{array}$ & Yes/yes & Yes & No & No & Yes & Yes \\
\hline Maffei et al. ${ }^{23}$ & $\begin{array}{l}\text { Patient selection } \\
\text { method NS }\end{array}$ & Yes/yes & Yes & No & No & Yes & Yes \\
\hline Ancora et al. ${ }^{39}$ & $\begin{array}{l}\text { Patient selection } \\
\text { method NS }\end{array}$ & Yes/yes & Yes & No & No & Yes & Yes \\
\hline Mousavi et al. ${ }^{38}$ & $\begin{array}{l}\text { Patient selection } \\
\text { method NS }\end{array}$ & NS & Yes & No & No & Yes & Yes \\
\hline Akingbola et al. ${ }^{34}$ & $\begin{array}{l}\text { Patient selection } \\
\text { method NS }\end{array}$ & Yes/yes & Yes & Yes & No & Yes & Yes \\
\hline Dilli et al. ${ }^{33}$ & $\begin{array}{l}\text { Patient selection } \\
\text { method NS }\end{array}$ & Yes/yes & Yes & No & No & Yes & Yes \\
\hline Teo and Shah ${ }^{31}$ & $\begin{array}{l}\text { Patient selection } \\
\text { method NS }\end{array}$ & Yes/yes & Yes & No & No & Yes & Yes \\
\hline Parra et al. ${ }^{29}$ & $\begin{array}{l}\text { Patient selection } \\
\text { method NS }\end{array}$ & Yes/yes & Yes & No & No & Yes & Yes \\
\hline $\begin{array}{l}\text { Vivar del Hoyo } \\
\text { et al. }{ }^{24}\end{array}$ & $\begin{array}{l}\text { Patient selection } \\
\text { method NS }\end{array}$ & Yes/yes & Yes & No & No & Yes & Yes \\
\hline Yong et al. ${ }^{42}$ & Yes & Yes/yes & Yes & No & No & Yes & Yes \\
\hline Han et al. ${ }^{37}$ & $\begin{array}{l}\text { Patient selection } \\
\text { method NS }\end{array}$ & Yes/yes & Yes & No & No & Yes & Yes \\
\hline Isik et al. ${ }^{36}$ & $\begin{array}{l}\text { Patient selection } \\
\text { method NS }\end{array}$ & Yes/yes & Yes & No & No & Yes & Yes \\
\hline Mintoft et al. ${ }^{26}$ & $\begin{array}{l}\text { Patient selection } \\
\text { method NS }\end{array}$ & Yes/yes & Yes & No & No & Yes & Yes \\
\hline $\begin{array}{l}\text { Kuttysankaran } \\
\text { et al. } .^{32}\end{array}$ & $\begin{array}{l}\text { Patient selection } \\
\text { method NS }\end{array}$ & Yes/yes & Yes & No & No & Yes & Yes \\
\hline $\begin{array}{l}\text { Weeraskera } \\
\text { et al. } .^{27}\end{array}$ & $\begin{array}{l}\text { Patient selection } \\
\text { method NS }\end{array}$ & Yes/yes & Yes & No & No & Yes & Yes \\
\hline
\end{tabular}


adverse events identified as being drug related. Reports of mild decreases in blood pressure were in newborns receiving inotropes for hypotension before TNG ointment was applied, ${ }^{25,40}$ or the low blood pressure resolved spontaneously without intervention. The results of our review point toward the efficacy of TNG ointment for the treatment of neonatal peripheral tissue ischemia. Further investigation through experimental trials is needed to confirm the optimal efficacy-safety profile of this drug.

In contrast, the efficacy profile of GTN patches in this review is less favourable. Although the GTN dose administered in the 2 cases with methemoglobinemia was higher than the doses administered in any of the other studies and the amount of data available is limited, the occurrence of serious adverse events raises concerns about the use of GTN patches in this vulnerable population. Furthermore, there may be less dosing flexibility with a patch than with an ointment, which may increase the risk of adverse events (overdosing) or therapeutic failure (underdosing). As for the TNG spray, evidence is available only for 1 patient and thus conclusions cannot be drawn regarding the efficacy and safety of this product.

Peripheral tissue ischemia is a well-known and serious morbidity among ELBW infants. Given the low weight of these patients and their high rate of comorbidities, most available therapeutic options for older children and adults are less viable in this population. Surgical or radiologic thromboembolectomy is not considered an option for ELBW newborns. ${ }^{46}$ The use of thrombolytic agents or anticoagulants is a challenge, considering the limited evidence for the use of these treatments among this group and the high risk of adverse events. ${ }^{47,48}$ Therefore, critically ill neonates in the NICU with a limb-threatening acute event present a therapeutic challenge. Although no randomized controlled trials have been published, the current evidence on the use of TNG ointment in newborns with peripheral tissue ischemia suggests that it has an acceptable efficacy-safety profile.

If TNG ointment remains unavailable in Canada indefinitely, the care of newborns in Canadian NICUs may be adversely affected. ${ }^{49}$ To our knowledge, this product continues to be marketed in comparable jurisdictions such as the United States and the United Kingdom, where, although it is used off label, it remains available for the prevention of potentially life-altering morbidity in sick newborns. ${ }^{50,51}$ This drug shortage is a clear example of a how national drug shortage can seriously threaten patient safety and quality of care, especially for the vulnerable patients of NICUs. ${ }^{49}$

The multistakeholder steering committee on drug shortages in Canada has established guidelines on the best strategies to identify risks and the optimal approaches to address manufacturing-related drugs shortages. ${ }^{52}$ A collaborative effort by representatives from Health Canada, other federal and provincial government departments and the pharmaceutical industry as well as health care providers is required so that adverse outcomes in this patient population can be avoided.

\section{Limitations}

We attempted to collect all available literature on the efficacy and safety of TNG products for salvage therapy of neonatal tissue ischemia. Nevertheless, this review consisted of studies that are at the lowest level of medical evidence and are subject to vulnerabilities such as danger of overinterpretation, publication bias and inability to establish cause-effect relationships. As the evidence on this topic was reported exclusively using case report and case series methodology, we were unable to compare outcomes among infants who were exposed and unexposed to TNG products. We were unable to assign a risk of bias for each included study, as the tool that we used for data quality assessment does not specify a cut-off score. ${ }^{21}$ Another limitation is that the protocol for our review was not registered or published.

\section{Conclusion}

The best currently available evidence suggests that TNG ointment has a favourable efficacy-safety profile in the prevention of morbidities associated with peripheral tissue ischemia in newborns. With the indefinite discontinuation of TNG ointment by the Canadian manufacturer, clinicians treating critically ill NICU patients have lost a valuable therapeutic option, and no good alternative is currently available. Timely engagement of stakeholders is needed to address the severe impact that this important drug shortage might have on the care of newborns in Canada.

\section{References}

1. Shalabi M, Adel M, Yoon E, et al. Risk of infection using peripherally inserted central and umbilical catheters in preterm neonates. Pediatrics 2015;136:1073-9.

2. Scott-Warren VL, Morley RB. Paediatric vascular access. BfA Educ 2015;15:199-206.

3. Wilkins CE, Emmerson AJB. Extravasation injuries on regional neonatal units. Arch Dis Child Fetal Neonatal Ed 2004;89:F274-5.

4. Kostogloudis N, Demiri E, Tsimponis A, et al. Severe extravasation injuries in neonates: a report of 34 cases. Pediatr Dermatol 2015;32:830-5.

5. Cartlidge PH, Fox PE, Rutter N. The scars of newborn intensive care. Early Hum Dev 1990;21:1-10.

6. Paquette $\mathrm{V}$, McGloin $\mathrm{R}$, Northway $\mathrm{T}$, et al. Describing intravenous extravasation in children (DIVE study). Can f Hosp Pharm 2011;64:340-5.

7. Arshad A, McCarthy MJ. Management of limb ischaemia in the neonate and infant. Eur 7 Vasc Endovasc Surg 2009;38:61-5.

8. Corbett M, Marshall D, Harden M, et al. Treating extravasation injuries in infants and young children: a scoping review and survey of UK NHS practice. BMC Pediatr 2019;19:6.

9. Szvetko A, Hurrion E, Dunn A, et al. Axillary artery thrombosis in a neonate in utero : a case report. Case Rep Pediatr 2014;2014:417147.

10. Ismail HIHM, Phak NH, Thomas T. Paediatric protocols for Malaysian hospitals. 3rd ed. Wilayah Persekutuan Putrajaya (Malaysia): Kementerian Kesiharan Malaysia; 2012. Available: https://mpaeds.my/wp-content/uploads/2018/04/ Paediatric-Protocols-for-Malaysian-Hospitals-Third-Edition.pdf (accessed 2020 Aug. 28).

11. Bennett S. Nitroglycerin for peripheral ischemia: East Bay newborn specialists suideline. Oakland (CA): Neonatology Administrative Office — East Bay Newborn Specialists; 2010. Available: www.eastbaynewborn.com/docs/Nitroglycerin for Peripheral Ischemia Guideline 09-28-10.pdf (accessed 2020 Aug. 28).

12. Neonatal Clinical Practice Guideline: management of peripheral IV access devices and extravasation injuries in neonates. Winnipeg: Winnipeg Regional Health Authority; 2017. Available: https://professionals.wrha.mb.ca/old/extranet/eipt/files/ EIPT-035-23.pdf (accessed 2020 Aug. 28).

13. Adiotomre P, Elliot L. Yorkshire \& Humber Neonatal Network (South) Clinical Guideline: extravasation injuries in neonates. Yorkshire and Humber Neonatal Operational Delivery Network; 2018. Available: www.networks.nhs.uk/nhs-networks/ yorkshire-humber-neonatal-odn/guidelines-1/guidelines-new/skin/extravasation -injuries (accessed 2020 Aug. 28).

14. Neonatal medication monograph: glyceryl trinitrate (GTN). Perth (AU): Department of Health Western Australia: 2019. Available: www.wnhs.health.wa.gov. $\mathrm{au} / \sim$ media/Files/Hospitals/WNHS/For health professionals/Clinical guidelines/NCCU/Drug Protocols/GlycerylTrinitrate.pdf (accessed 2020 Aug. 28).

15. Peripheral arterial lines in the neonate. Auckland (NZ): Starship; 2019. Available: www.starship.org.nz/guidelines/peripheral-arterial-lines/ (accessed 2020 Aug. 28).

16. Kim KH, Kerndt C, Schaller DJ. Nitroglycerin. In: StatPearls. Treasure Island (FL): StatPearls Publishing; 2020. Available: www.ncbi.nlm.nih.gov/books/ NBK482382/ (accessed 2020 Oct. 10). 
17. Drug shortage report for NITROL. Saint-Laurent (QC): Drug Shortages Canada; updated 2019 Aug. 24. Available: https://www.drugshortagescanada. ca/shortage/19793 (accessed 2020 Aug. 28).

18. Liberati A, Altman DG, Tetzlaff J, et al. The PRISMA statement for reporting systematic reviews and meta-analyses of studies that evaluate healthcare interventions: explanation and elaboration. BMF 2009;339:b2700.

19. Aromatari E, Munn Z, editors. Chapter 1: JBI systematic reviews. In: FBI manual for evidence synthesis. Adelaide (AU): Joanna Briggs Institute; 2020. https:// wiki.joannabriggs.org/display/MANUAL/Chapter+1\%3A+JBI+Systematic+ Reviews (accessed 2020 Aug. 28).

20. McGowan J, Sampson M, Salzwedel DM, et al. PRESS peer review of electronic search strategies: 2015 guideline explanation and elaboration (PRESS E\&E) [methods and guidelines]. Ottawa: Canadian Agency for Drugs and Technologies in Health; 2016:40-6. Available: www.cadth.ca/press-2015-guideline -explanation-and-elaboration (accessed 2020 Oct. 10).

21. Murad MH, Sultan S, Haffar S, et al. Methodological quality and synthesis of case series and case reports. BM7 Evid Based Med 2018;23:60-3.

22. Samiee-Zafarghandy S, Van Den Anker JN, Ben Fadel N. Topical nitroglycerin in neonates with tissue injury: a case report and review of the literature. Paediatr Child Health 2014;19:9-12.

23. Maffei G, Rinaldi M, Rinaldi G. Resolution of peripheral tissue ischemia secondary to arterial vasospasm following treatment with a topical nitroglycerin device in two newborns: case reports. 7 Perinat Med 2006;34:252.

24. Vivar del Hoyo P, Sánchez Ruiz P, Ludeña del Río M, et al. Use of topical nitroglycerin in newborns with ischaemic injuries after vascular cannulation [article in Spanish]. An Pediatr (Barc) 2016;85:155-6.

25. Baserga MC, Puri A, Sola A. The use of topical nitroglycerine ointment to treat peripheral tissue ischemia secondary to arterial line complications in neonates. 7 Perinatol 2002;22:416-9.

26. Mintoft A, Williams E, Harris C, et al. Methemoglobinemia during the use of glyceryl trinitrate patches in neonates: two case reports. A7P Rep 2018;8:e227-9.

27. Weerasekera M, Lakmini C, Imbulana NS, et al. Topical nitroglycerine in management of peripheral ischaemia in a neonate following arterial cannulation. Sri Lanka 7 Child Health 2019;48:263-5.

28. O'Reilly C, McKay F, Duffy P, et al. Glyceryl trinitrate in skin necrosis caused by extravasation of parenteral nutrition. Lancet 1988;2:565-6.

29. Parra D, Zuker R, Connolly B. Brachial pseudoaneurysm of the neonate with partial response to thrombin injections and late spontaneous thrombosis and regression during expectant management. BFR Case Rep 2016;2:20150383.

30. Vasquez P, Burd A, Mehta R, et al. Resolution of peripheral artery catheterinduced ischemic injury following prolonged treatment with topical nitroglycerin ointment in a newborn: a case report. 7 Perinatol 2003;23:348-50.

31. Teo MC, Shah VA. Digital ischaemia following inadvertent arterial cannulation of a peripherally inserted central catheter in a very low birth weight infant. Singapore Med 7 2015;56:482-3.

32. Kuttysankaran R, Ramaiah S, Popescu O. Spontaneous femoral artery thrombosis in a newborn infant: case report. Perinatologia 2018;1:22-4.

33. Dilli D, Özyazici E, Fettah N, et al. Rupture and displacement of umbilical arterial catheter: bilateral arterial occlusion in a very low birth weight preterm. Arch Argent Pediatr 2015;113:e283-5.

34. Akingbola O, Singh D, Steiner R, et al. High-dose tissue plasminogen activator, topical nitroglycerin, and heparin for severe ischemic injury in a neonate. Clin Pediatr (Phila) 2012;51:1095-8.

35. Mosalli R, Elbaz M, Paes B. Topical nitroglycerine for neonatal arterial associated peripheral ischemia following cannulation: a case report and comprehensive literature review. Case Rep Pediatr 2013;2013:608516.

36. Işı DU, Demirel N, Erol S, et al. A rare complication of phenytoin infusion in newborn: purple glove syndrome. Balkan Med 7 2017;34:584-5.

37. Han YS, Song S, Sung TJ, et al. Successful management of severe peripheral tissue ischemia after arterial catheterization in micro preemies using humidification and topical nitroglycerin. Neonatal Med 2017;24:197-201.

38. Mousavi SA, Sahebpour AA, Shahmohammadi S. Neonatal gangrene of the extremity: a complication of umbilical catheterization. Pak $\mathcal{F}$ Med Sci 2010; 26:488-9.

39. Ancora G, Soffritti S, Faldella G. Diffuse and severe ischemic injury of the extremities: a complication of umbilical vein catheterization. Am 7 Perinatol 2006;23:341-4.

40. Wong AF, McCulloch LM, Sola A. Treatment of peripheral tissue ischemia with topical nitroglycerin ointment in neonates. 7 Pediatr 1992;121:980-3.

41. Varughese M, Koh TH. Successful use of topical nitroglycerine in ischaemia associated with umbilical arterial line in a neonate. 7 Perinatol 2001;21:556-8.

42. Yong J, Rajan C, Molnar Z, et al. Single UK tertiary neonatal unit experiences of neonatal arterial thrombosis [abstract]. Br 7 Haematol 2016;173(Suppl 1):5-178.

43. Denkler KA, Cohen BE. Reversal of dopamine extravasation injury with topical nitroglycerin ointment. Plast Reconstr Surg 1989;84:811-3.

44. Kamar R, van Vonderen JJ, Lopriore E, et al. Nitroglycerin for severe ischaemic injury after peripheral arterial line in a preterm infant. Acta Paediatr 2013;102:e144-5.
45. Okogbaa JI, Onor IO, Arije OA, et al. Phenytoin-induced purple glove syndrome: a case report and review of the literature. Hosp Pharm 2015;50:391-5.

46. Ulrich TJB, Ellsworth MA, Lang TR. Emergent thrombectomy in a neonate with an upper extremity arterial thrombus. A7P Rep 2014;4:41-4.

47. Kayıran PG, Gürakan B, Kayıran SM. Successful treatment of arterial thrombus in an extremely low-birth-weight preterm neonate. Pediatr Neonatol 2013;54:60-2.

48. Romantsik O, Bruschettini M, Zappettini S, et al. Heparin for the treatment of thrombosis in neonates. Cochrane Database Syst Rev 2016;11:CD012185.

49. Ziesenitz VC, Fox E, Zocchi M, et al. Prescription drug shortages: impact on neonatal intensive care. Neonatology 2019;115:108-15.

50. Drugs@FDA: FDA-approved drugs. Silver Spring (MD): US Food and Drug Administration. Available: www.accessdata.fda.gov/scripts/cder/daf/index. cfm? event=overview.process\&ApplNo=087355 (accessed 2020 Aug. 27).

51. Williams RC, Caso RJ. Cellegy reports sale of Cellegy Australia to Epsilon pharmaceuticals. Washington (DC): US Securities and Exchange Commission; 2006. Available: www.sec.gov/Archives/edgar/data/887247/000114420406015377/ v040547_ex99-1.htm (accessed 2020 Aug. 27).

52. Drug supply in Canada: a multi-stakeholder responsibility — report of the Standing Committee on Health. 41st Parliament, 1st sess. Ottawa: House of Commons; 2012. Available: www.ourcommons.ca/DocumentViewer/en/41-1/ HESA/report-9 (accessed 2020 Aug. 27).

Affiliations: School of Nursing (Sushko), Faculty of Health Sciences, McMaster University, Hamilton, Ont.; Division of General Pediatrics (Litalien), Department of Pediatrics, and the Rosalind \& Morris Goodman Family Pediatric Formulations Centre, Centre hospitalier universitaire Sainte-Justine, Université de Montréal, Montréal, Que.; Department of Pharmacy (Ferruccio), Hamilton Health Sciences, Hamilton, Ont.; Rosalind \& Morris Goodman Family Pediatric Formulations Centre (Gilpin), Centre hospitalier universitaire Sainte-Justine, Université de Montréal, Montréal, Que.; Department of Emergency Medicine (MazerAmirshahi), MedStar Washington Hospital Center, Georgetown University School of Medicine, Washington, DC; Division of Pediatric Hematology/ Oncology (Chan), McMaster Children's Hospital, McMaster University, Hamilton, Ont.; Division of Clinical Pharmacology (van den Anker), Department of Pediatrics, Children's National Hospital, Washington, DC; Division of Paediatric Pharmacology and Pharmacometrics (van den Anker), University Children's Hospital, University of Basel, Basel, Switzerland; Division of Neonatology (Lacaze-Masmonteil), Department of Pediatrics, University of Calgary, Alberta Children's Hospital, Calgary, Alta.; Division of Neonatology (Samiee-Zafarghandy), Department of Pediatrics, McMaster Children's Hospital, McMaster University, Hamilton, Ont.

Contributors: All authors contributed substantially to the conception and design of the study, the acquisition of the data and the analysis and interpretation of the data. Katelyn Sushko and Samira SamieeZafarghandy drafted the article. All authors revised the article critically for important intellectual content, gave final approval of the version to be published and agreed to act as guarantors of the work.

Content licence: This is an Open Access article distributed in accordance with the terms of the Creative Commons Attribution (CC BY-NC-ND 4.0) licence, which permits use, distribution and reproduction in any medium, provided that the original publication is properly cited, the use is noncommercial (i.e., research or educational use), and no modifications or adaptations are made. See: https://creativecommons.org/licenses/by-nc-nd/4.0/

Data sharing: We used publicly available data for the analysis in this study (detailed in the Methods).

Acknowledgements: We thank Megan Fournier and Vivian Bui, pharmacists at McMaster Children's Hospital, and Dr. Gerhard Fusch, assistant professor in the Department of Pediatrics at McMaster University, for their contributions to the conceptualization of this systematic review. We also thank Jack Young and Denise Smith, librarians at McMaster University's Health Sciences Library, for their assistance in the development of our electronic search strategies.

Supplemental information: For reviewer comments and the original submission of this manuscript, please see www.cmajopen.ca/content/9/1/ E252/suppl/DC1. 